\title{
Age-related changes in the expression of schizophrenia susceptibility genes in the human prefrontal cortex
}

\author{
Carlo Colantuoni - Thomas M. Hyde - Shruti Mitkus • Andrew Joseph · Leah Sartorius • \\ Claudia Aguirre · Johanna Creswell $\cdot$ Elizabeth Johnson · Amy Deep-Soboslay • \\ Mary M. Herman · Barbara K. Lipska · Daniel R. Weinberger · Joel E. Kleinman
}

Published online: 13 June 2008

(c) Springer-Verlag 2008

Erratum to: Brain Struct Funct (2008)

DOI 10.1007/s00429-008-0181-5

In the published original version of the article, the last sentence of the abstract was incomplete and should read as follows:

All microarray data are available at NCBI's Gene Expression Omnibus: GEO Series accession number GSE11546 (http://www.ncbi.nlm.nih.gov/geo).

The online version of the original article can be found under doi:10.1007/s00429-008-0181-5.

C. Colantuoni $(\bowtie) \cdot$ T. M. Hyde - S. Mitkus - A. Joseph ·

L. Sartorius - C. Aguirre - J. Creswell - A. Deep-Soboslay ·

M. M. Herman · B. K. Lipska · D. R. Weinberger .

J. E. Kleinman

Clinical Brain Disorders Branch,

Genes Cognition and Psychosis Program,

IRP, NIMH, NIH, Bethesda, MD 20892, USA

e-mail: carlo@illuminatoart.com

C. Colantuoni - E. Johnson

Department of Biostatistics,

Johns Hopkins Bloomberg School of Public Health,

Baltimore, MD 21205, USA

C. Colantuoni

713 W. 36th St., Baltimore, MD 21211, USA 